\title{
Implications of Ali Sharīatī's Political Thought for Iranian Revolution
}

\author{
Dr. Muhammad Amin \\ Professor at University of Management \& Technology, Pakistan \\ Neelam Bano \\ PhD Scholar at University of Management \& Technology, Pakistan
}

\begin{abstract}
:
Dr. Ali Sharīati emerged on the intellectual horizon of Iran in the 1970's as a political activist. His political ideas are also considered as a forerunner for the Islamic revolution for having strong resonance within the Iranian society even now. This paper aims at shedding light by critically commenting on how he transformed the political thought of the Iranian people, particularly the youth, who brought about the Iranian revolution. Based on reviewing his political thought in the Iranian context, it is concluded that Shariatī declared that the self aware academic should strive to achieve such a revolutionary state where any form of imperialism, exploitation and capitalism find no place. It would end poverty, develop the economy and set up a society that is dynamic, just and classless.
\end{abstract}

Keywords: Ali Sharīatī, Political thought, Responsible intellectual, Revolution, Classless Society 


\section{Introduction}

\section{a) Political thought before Iranian revolution}

Iran is no stranger to revolution. In the 20th century, Iran had three revolutions but the Islamic Revolution of 1979 was the most remarkable and most remembered by the people as well as the rest of the world.

The Qajar dynasty ruled Iran until 1925 that underwent the first Revolution (constitutional revolution) in the $20^{\text {th }}$ century. Qajar period of domination was largely based on the support of two major European powers, ${ }^{\mathrm{i}}$ Great Britain and Russia were these two major Western bodies who introduced Western political ways in Iran. The Qajar dynasty, under the tutelage of Western bodies introduced "Shadow politics" instead of "real politics". ii A military man named Reza Kahn seized power in 1925 and overthrew the Qajar Shah to become Reza Shah Pahlavi. Nikki Keddie remarks that "as compared to the Qajars, Reza Shah acted with significant independence of foreign powers."

In 1941, Reza Shah was forcibly removed by the British and replaced by his son, Muhammad Reza Pahlavi. In the 1950s, a major political crisis developed over control of the oil industry. The Anglo-Iranian Oil Company (AIOC) remained completely free from Iranian governmental controls and monitoring."The frustration of Iranians grew as they were forced to pay high prices for Iranian oil, while the numbers of skilled Iranian workers dwindled." iv

The Shah's regime became increasingly repressive, vicious, corrupt, and profligate. The functional failures of his regime brought economic shortages and inflation. The Shah's support for the increase in OPEC petroleum price may also be a cause of the decrease in his support by Western politician and media. His foreign policy eventually caused him the most trouble. It is within the social, political and economic climate of the reign of the dictatorial and Western-allied Muhammad Reza Shah that the revolutionary discourse within Iran began to take shape.

Iranian intellectuals have been particularly passionate in their urge for change within their country. Intellectuals actually play the role of the soldier of the pen and spokesmen of the nation living in crises. As such Edward Said delineates an Intellectual in these words:

The intellectual is an individual endowed with a faculty for representing, embodying, articulating a message, a view, an attitude, philosophy or opinion to, as well as for, a public. And this role has an edge to it, and cannot be played without a sense of being someone whose place it is publicly to raise embarrassing questions, to confront orthodoxy and dogma (rather than to produce them), to be someone who cannot easily be co-opted by governments or corporations.

In the two decades, i.e. 1960's and 1970's Sharīatī's personality has been identified as the most influential one among the Iranian intellectuals. Sharīatī who died in London in June 1977, was among those who were the predecessors of Islamic Revolution in Iran 
His major aim was to make the Iranian Muslims aware of the fact that if they wanted themselves to be free from foreign control, then they have to follow their own Islamic heritage rather than adopting Western ideas.

\section{b) Purpose of study:}

This paper will discuss Iranian intellectual Alī Sharīatī, one of the great thinkers of the pre-Revolutionary era of the late 1960s and early 1970s, and the man who properly introduced the notion of "political spirituality" or revolutionary Islam in the region of Islam.

As an intellectual, Alī Sharīatī was very much aware of his social responsibility. He spent all of his time in the propagation of religion and transmission of Islamic ideas to young generation. ${ }^{v i} \mathrm{He}$ deployed great effort against what he called the evil temper of the modern age and, the withered root of which could be watered only by the renunciation of all things, by martyrdom, according to him. ${ }^{\text {vi }}$

This work mainly focuses to evaluate Sharīatî's political ideas and thought and implications of his thought on the Iranian revolution.

\section{c) Significance of the study:}

Sharīatī's historical significance should not be forgotten as many of his ideas are still workable today. He was an Intellectual whose ideas were ultimately directed to a resurgence and revival of Islam and Muslim society. Sharīatī propagated his ideas during the days when the Islamic revolution in Iran, which was in the process of being shaped up. ${ }^{\text {viii }}$ Shariatî's contribution to shape the ideologies concerning revolution will be remembered long not only because of their novelty, but also because they precede the Islamic Revolution of Iran.

Sharīatī's political ideas and thought influenced those intellectuals and young Iranians who played an active role in the movement of the Revolution and hence, Sharīatī's role is a significant one in producing the idea of Islam as a dynamic force among a generation and a class of young Iranians who would otherwise have become even more alienated from Islam.

\section{His Life:}

Alī Sharīatī was born in 1933 in an Iranian village called Mazinan. The village is about 70 kilometers from Sabzavar on the edge of the Kavir ${ }^{\text {ix }}$ desert. His father Muhammad Taqi, a religious scholar himself taught him the technique of systematic and rational perception and filled him with a moral and political fortitude. ${ }^{\mathrm{x}}$

Both father and son were active supporters of Mohammad Mosaddeq and were briefly detained in 1956 for their support of Mosaddeq. As such, a young Ali Sharīatī was exposed to a wide range of political and social thought.

From his early childhood to the youth, the traces of a strong belief were eminent. After completing his graduation from Mashad he adopted the profession of teaching and by the time furthered himself as an ardent advocate of his thoughts and ideologies. 
Sharīatī traveled to Paris in 1960 after receiving a scholarship to study at the Sorbonne. He received a doctorate for the translation of, and commentary on, a Medieval Persian text into French. But he was primarily interested in sociology, philosophy and religious history. During his stay in Paris, he had interacted with most of the well educated people, scholars and writers such as "Bergson, Albert Camus, Sartre, Schwartz and also the works of philosophers and sociologists such as Gurwitsch and Berque, and Islamologists such as Louis Massignon". ${ }^{\mathrm{i}}$

During his stay in France, Shariatī coincided with the turbulent time of the Algerian revolt, when different parts of Europe, including the scholars and sociologists were accepting the position, constructive and harmful, on the fortune of the Muslim people who had been subjected to imperialism for more than a century and were busy in a ferocious Jihad, "a life - and - death struggle", carrying their fight into the France itself. Shariatī showed great interest and consideration to what was happening in Algeria, for he never considered himself detached from the anti imperialist struggle $\mathrm{e}^{\mathrm{xii}}$

When he re-entered Iran, SAVAK ${ }^{\text {xiii }}$ arrested him because of his activism in France. After his release from prison he joined the Mashad University and influenced the students through his speeches and eloquent mode of expression. SAVAK gave him a tough time, mainly because of his influential speeches to the university students. His major effort is not towards his own personality, but to draw a distinctive line between the right and wrong, and he was fully devoted even to pledge his life for that line. He suffered confinements and restrictions and was mentally tortured to the extent that he left Iran and died of a heart attack in 1977.

\section{Ali Sharīatī's political perspectives}

The main point in his political ideology is his attempt to redefine the terms of "Politics" and Siasat (the word used for politics in Persian). As per his perception Siasat deals with anarchy, endeavoring to reshape ideologies, institutions, and the conscience of a transitory society. Siasat is not concerned with the daily problems of government. It is a way to change the social condition of the poeple and provide welfare to those in need of it.

Politics, on the other hand, deals with man and the world as if it really is around him, his needs and demands that concern his present. To be more accurate we can say that Siasat molds the public accord whereas politics is molded on it.

According to this new definition presented by Sharīatī, politics should be an affair of the enlightened and intellectual members of society as it is a struggle through hardships in pursuit of real happiness.

For Sharīatī, in actuality, 'authentic intellectual' whether religious or irreligious is one who sticks to the logical, societal and political struggle for revolution: "If you're not in the struggle, it doesn't make much difference whether you are in the mosque or the bar." "xiv Thus politics is a reference to "Being" and Siasat is of "Becoming" integrity of thought and practices and elevation of character is the dire need for those who run the business of Siasat.

Sharīatī believed in "engaged democracy". He argued that 
In the absence of a charismatic leader, the leader may not be elected by popular vote, but selected by the experts who are trusted by people and he would not be responsible to the populace, but principles of guidance according to which he has to move the society towards its higher goal. ${ }^{\mathrm{xv}}$

In Sharīatî's proposed model of government there are two main leaders;

a)A charismatic ruler

b)A chosen ruler who is not responsible to the people, but nevertheless bound by Islamic principles. ${ }^{\text {xi }}$

Shariatī's political theory focused on the point that a Third World country such as Iran requires a revolution that eradicates all forms of imperialism besides revitalizing the country's culture, heritage and national identity.

Sharīatī also redefines Ummat as the league of Islamic Humanists that can be equated to the League of communists in its endeavour to shape up a classless society. Shariatī denounces the ills of the society as "imperialism", class exploitation, class oppression, class inequality and also targets the "vulgar Marxism," and "Clericalism" of the ruling oligarchy.

\section{Revolutionary Ideology:}

Sharīatī termed Shi'ism as "Islamology" (Islamshenasi) which is a revolutionary ideology that transcends all aspects of life including politics. A true Islamshenasi is inspirational for a believer reinforcing in him and has the power to confront exploitation, repression, and social discrimination. He considered the Shî'ism culture basically radical and compatible with the aims of the revolution.

Sharīatī is of the opinion that the ruling class was using Shia Islam for their purpose. His project was to reclaim the "real" Shi'i religion. In his article Red Shī’̄īsm vs. Black Shī’̄ism, Sharīatī discussed the dualism in the past of Shīah religion. According to him "Red Shī'īsm" is more concerned with social justice and salvation for the masses.

He considers "Black Shī'issm as the diverged form of the religion, which is out of touch with the needs of the masses and is led by both monarchy and clergy, and came to be recognized in Iran under the influence Safavids." xvii 


\section{Enlightened Souls:}

Shariatī believed the free thinkers (the rushanfekran) are responsible for carrying forth the revolution. Shariatī added that the role of "Enlightened Souls" xviii in directing their society to revolutionary change. In this respect, he highlighted the failure of the Western trained scholars' who had influential connections with the peoples of the nations they claim to liberate or lead, with the resulting "gravest tragedy" in reality causative to further colonization. Sharīatī argues that enlightened souls are those particular intellectuals who have an ability to identify the problems of their society and increase the awareness of the people to comprehend and resolve those problems.According to Sharīatī, "An Intellectual is one who is conscious of his own 'humanistic status' in a specific social and historical time and place."xix

Sharīatī's description of an "Enlightened Soul" is noteworthy for its review of the revolutionary struggle. "If we believe as true free-thinking intellectuals, what must be our relationship with the society and what path should we follow?"xx

\section{Martyrdom as Revolutionary Weapon}

Martyrdom according to Sharīatī is the life and soul for revolution. An important aspect of Shi'te ideology consists of its promotion of the philosophy of martyrdom. For him, it was a tradition followed by the heroes of history. In this regard, Hazrat Hussain's martyrdom is exemplary, as an amalgam of true Islamic beliefs and a permanent sign of faith's survival against oppression.

Martyrdom is "the protective shield" for future generations. It is essential for their growth and survival, as Sharīatī believes that Jihad has changed Shi'ties from passive guardians of the cemeteries to energetic supporters of Hazrat 'Alī (R.A) and Hazrat Hussain (R.A), as torchbearers of truth: "In the permanent battle of history everywhere and everyplace, all fields are Karbala, all months are Moharram, and all days are Ashura."xxi

Hazrat Hussain's martyrdom is an "invitation" forever and to all to "die" when you cannot kill, when religion is modified, when a protest is snubbed by the powers and whenever leaders mislead. Sharīatī says: "It is an invitation to all ages and generations that if you cannot kill, die" "xxii

\section{Role of Ali Sharīatî's Political perspectives on Iranian Revolution}

Alī Sharīatī's life spans during the reign of Shah Mohammad Reza Pahlavi when the main concern of royalty and a class of intellectuals was to push Iran* from its alleged traditional status towards a Western-defined state of modernity and reach to the Great Civilization. They considered civil society and democratic institutions as the only way to promote modernity. Consequently modernity was one of the main concerns of the public that led to the demise of the Pahlavi dynasty.

Many of the contemporary politicians were very much inspired by Iranian communist group (The Tudeh Party of Iran), who considered Western modernity as satanic and colonizing. 
Apart from such ideologies, Sharīatī was genuinely trying to return to the original Iranian identity along with his deep knowledge of the Western modernity. He had a strong ideological view of modernity and was deeply inspired by the totalitarian Russian Marxism but at the same time believed in a revival of Islamic origins. The negative view of the Western modernity was empowered with the establishment of the Islamic Republic in 1979. During this period all aspects of modernity were rejected and a return to Islamic origins was offered instead. As Rehnema states:

A product of the transformation initiated by Reza Shah, during the reign of Muhammad Reza Shah, 'Alī Sharīatī became actively involved in, and was greatly influenced by, the multifarious changes that Irani society underwent in terms of economics, politics, ethics, culture, poetry, prose, film, journalism and even religion. ${ }^{\text {xiii }}$

Although Sharīatī was not a politician, but through his powers of oration, he fired up the imagination of the younger generation and created a deep and enduring impact on all listeners. He actually targeted younger generation who were already influenced by Western culture and alienated from Islam. As he was recognized as Western intellectual he used latest intellectual jargon for relaying what he wanted to see to the young generation that while Marxism and Existentialism had failed to solve the problems of the modern man but Islam had the answer. He hadn't only addressed the Iranian audience, but also passed on his massage all over the world. Ali Shariatî's contribution to the Islamic Revolution in Iran was two fold.

First, he created an awareness of Islamic values and heritage among the Iranian middle class, particularly the youth of the country, which in the course of time paved the way for the Revolution. Tawheed is the basis of Sharīatī's ideology as he considers the whole world as a unit, a single living organism in terms of tawheed. "My World-View consists of tawheed in the sense of God is of course accepted by all monotheists. But tawheed as a world view in the sense I intend in my theory, means regarding the whole universe as a unity". xxiv Sharīatī rejects all views of naturalism materialism and dualism. He criticized the Cartesian Dualism (also called Mind Body dualism) which divides the universe in matter and metaphysics. In Shariatî's view tawheed allows no dichotomy, all is a unity - a unity among three hypostases, God, Nature and Man. "I do not believe in pantheism, polytheism, Trinitarians, or dualism, but only in Tawheed- monotheism., "xxv

Sharīatī considered Shi'ism, as a revolutionary ideology that encompasses every field of life, including politics and inspired true believers to struggle for justice, equality, and classless society.

Sharīatī's master stroke was to bring to life the tale of Ashura and Imām Hussain, Zainab's captivity and the captivity of Imām Hussain's kith and kin, and the events of Karbala as a whole. He was, 
in all fairness, an expert - with a magical touch when it came to cultivating this story and bringing Shi'is' blood to the boil; no one has been able to surpass him in this. ${ }^{\text {xvi }}$

He further pleaded that Hussein's martyrdom at Kerbala contained one loud and clear messsage that all Shi'is had the sacred duty to oppose, defy and revolt against world imperialism and multinational corporations.

His second basic contribution was to make the people conscious of their deprivation and exploitation. His message rang loud and clear in educating and discriminating minds.

According to Sharīatī, Qurān advocates the distribution of power to people on political, economic and religious grounds. Qurān equates Allāh and Al-nas and advocates human society as being representative of Allāh on earth. The aphoristic view of declaring 'property to God' is in fact that wealth belongs to the people and the idea that 'Religion is for Allāh' means that religion is an issue of people; it is not just a concern of clergy! This notion is opposite to Khomeini's "vilayat-i-faqih"; Rule is an attribute of God means that politics is a matter of people.

Sharīatī strongly presented the view that the ruling class had used Islam as a tool to modify the thoughts of masses to be more submissive. The ruling class promoted a modified understanding of Islam exploiting obsession for conventional Islam. Such an understanding resulted in a set of rituals in the fields of education and training. This modified understanding was used as a shield to protect financially and politically developed conventional Islam as a stubborn Ideology.

Sharīatī met such 'fabricated vision' with his propaganda for highlighting the need of Intellectuals capable of confronting social conflicts utilizing revolutionary Ideology of Islam. Shariatī articulates that dialectics remain at the center of Islam. There has always been a tussle of original Islam with intolerant Islam."The war of religion against religion is constant in history, a war of Tawheed against shirk, of justice against discrimination". xvii

From his early youth, Sharīatī directed his entire energy and enormous talent towards arousing people from the deep slumber into which they had fallen. It was his dynamic and progressive understanding of Islam, which inspired the youth with fresh hope and firm belief that a return to immaculate and progressive Islam would inexorably bring revolution as well.

The role of other Iranian leaders as Motahari, Taleqani, Bazargan and especially Ayatollah Khomeini could not be minimized who prepared the ground for the revolution through their writings and speeches. However, Ali Sharīatī played a decisive role in making a success of the revolution. Sharīatī is not well known as Khomieni because the Revolutionary movement was actually shaped by the powerful leadership of Khomieni. Khomieni had appeared as an outstanding leader as he audaciously attacked the regime and directly held the Shah responsible for all the evils besetting Iran. While confronting secular authority he did not restrict himself to criticism of just imperial measures, but he also demanded the truly Islamic state.

On the other hand Shariatî used the similes and the analogy that mentioned the sufferings of the people at the hands of brutal oppressors in the past 
instead of confronting secular authority and making direct references to the excesses of the Pahlavi regime. As he takes the Surah Al Rum as a parable illustrating the ways how the Islamic power was able to overcome super powers, the Sassanid's and the Byzantine Empire. In this commentary, he refers to the verse "The Romans were defeated," and he is of the view that the time has come now to defeat the super powers of the today's world. ${ }^{\text {xxviii }}$

"Conditions today are very similar. In fact, not even the terminology has changed. East and West rule the world while the Muslims, who are in the middle, are considered part of the Third World. Unfortunately, many intellectuals who have been overcome by the present superpowers believe that the survival of the Third World nations depends on their allegiance to one of these powers. Of course, such a position is contrary to the Islamic belief that Allāh is the Almighty and Omnipotent." xxix

In 1964 when Khomeini was in exile Sharīatī kept the revolutionary movement going. As Khomieni has supplied the strategic and political leadership, Shariatī has supplied the intellectual content for their commitment to the revolutionary movement. He did carry on his work in a substantial way. In the words of a foreign observer: Shariatī paved the way for Khomeini in the minds of many secular and intellectual Iranians.

\section{Conclusion}

Sharīatī never ceases to be a revolutionist in his perception of dealing with the world. His works reflect the deep, thought-provoking and challenging ideologies. He clings to his desires and commitment to the cause of societal righteousness, but according to his own definitions. He always asks for 'What ought to be' instead to be complacent on 'what really is'.

He inclines to sacrifice according to the philosophy of Martyrdom originally adapted from the martyrdom of Hazrat Hussain (R.A). He is aggressive, stimulating and revolutionary approach which originated from that strong religious and cultural background he came from. Some of his works give the impression that he was only concerned by the usefulness of Shi a Islam for revolution and that his faith from his realization that it put forth the desired goals maximizing societal change and shape the society into his mold.

Sharīatī deprecates "imperialism" and "class inequality" which are longer term enemies of society. He focused much of his polemics against "Profane Marxism," that had been ardently accepted by Iranian intellectuals, particularly the clerical assortment that had been promulgated by the ruling class for over twelve centuries in order to stupefy the exploited masses. Sharīatī affected a considerable number of revolutionaries through his political ideologies. It was a result of his political ideologies that the youth at that time conceived an alluring image of Islam. In fact, this phenomenon resulted in Khoemeni's elevation from a religious leader to a revolutionary leader and spiritual head. Those who joined Khoemeni to set up the Islamic ideology and Islamic state were affected by Sharīatī's innovatory theories and thus Shariatī can be regarded as the forerunner of Islamic revolution. 


\section{Selected Bibliography}

- Sharīatī, Alī. What is to be done? The Enlightened Thinkers And An Islamic Renaissance. Houston: IRIS, 1986.

- Sharīatī, Alī. Religion vs. Religion, trans. Laleh Bakhtiar. Chicago: Kazi Publications, 2010

- Sharīatī, Alī. School of Thought and Action: Islamic Renaissance Series. Edited by Bakhtiar Laleh. Chicago: Kazi Publications, 2012.

- Sharīatī, 'Alī. On the Sociology of Islam. Translated by Hamid Algar. Berkeley: Mizan Press, 1979.

- Sharīatī, Alī. Man and Islam, Translated by Marjani. Houston: FILINC, 1981

- Sharīatī, Alī. Martyrdom: Arise And Bear Witness, Translated by Ghassemy. Teheran: Ministry of Islamic Guidance, 1981.

- Sharīatī, Alī. From where Shall We Begin and The Machine in the Captivity of Mechanism. Ohio: Free Islamic Literature, 1980.

- Abrahamian, Ervand. Alī Sharīatīi: ideologue of the Iranian revolution”, In Social Movements in the Middle East, edited by Burk, Edmund. Los Angeles: University of California Press, 1993.

- Chatterjee, kingshuk. Alī Sharīatī and the Shaping of Political Islam in Iran. USA: Palgrave Macmillan, 2011.

- Rahnema, Alī. An Islamic Utopian: A Political Biography of 'Al̄̄ Sharīatī. London: I.B. Tauris, 1998.

- Ahmad, Ishtiaque. "Political Philosophy of Iran", Journal of Peace Studies 12, no 1, (2005): 1-5. http://www.icpsnet.org.

- Abrahamian, Ervand. "Ali Shari'ati: Ideologue of the Iranian Revolution", Middle East Research and Information Project, no 102, (1982): 24-28. http://www.jstor.org.

- Abedi, Mehbi. "Ali Sharīatī: The Architect of the 1979 Islamic Revolution of Iran” , Taylor \& Francis, Ltd Vol. 19, No. 3/4 (1986): 229-234. http://www.jstor.org.

- Akhavi, Shahrough. "Islam, Politics and Society in the Thought of Ayatullah Khomeini, Ayatullah Taliqani and AliSharīatî̀', Taylor \& Francis, Vol. 24, No. 4 (1988): 404-431. http://www.jstor.org.

- Shamsaei, Maryam. "Iranian Religious Intellectuals and the Modernization Debate”, International Journal of Humanities and Social Science, Vol. 1, Issue 1 (2012): 40-44. http://iosrjournals.org.

- Shamsaei Maryam, Shah Hazim. "Science and Government according to Iranian Thinkers", International Journal of Humanities and Social Science, Vol. 2 Issue 1 (2013): 64-74. http://www.ijhssi.org.

- Brad, Hanson. "The "Westoxication" of Iran: Depictions and Reactions of Behrangi, al-e Ahmad, and Shariati", International Journal of Middle East Studies, Vol. 15, No. 1 (1983): 1-23. http://www.jstor.org/stable/162924.

- Kamran, Matin. "The -Alchemist of Revolution: Ali Shariati's Political Thought in International Context", Spectrum Journal of Global Studies Vol. 6, No. 1

- Ahmad Ashraf and Ali Banuazizi, "The State, Classes and Modes of Mobilization in the Iranian Revolution", State, Culture, and Society Vol. 1, No. 3 (1985): 3-40. http://www.jstor.org/stable/20006815. 
i. Nikki R. Keddie, Modern Iran: Roots and Results of Revolution, (New Haven: Yale University Press 2006), 38.

ii Ibid., 36.

iii Ibid.

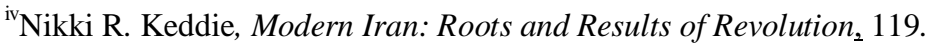

${ }^{\vee}$ Edward Said, Representations of the Intellectual: The 1993 Reith Lecture (New York: Pantheon Books 1994), 11.

${ }^{\text {vi }}$ Sharīatī, 'Alī, On the Sociology of Islam. Translated by Hamid Algar(Berkeley: Mizan Press, 1979),27.

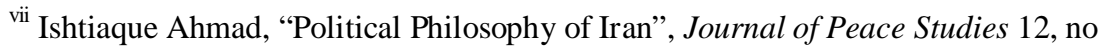
1, (2005): 1 .

viii Chatterjee kingshuk, Ali Sharīatī and the Shaping of Political Islam in Iran(USA: Palgrave Macmillan,

2011), 13.

${ }^{i x}$ Kavir also known as Kavir-e Namak or Great Salt Desert is a large desert lying in the middle of the Iranian Plateau.

${ }^{x}$ Alī Rehnma, An Islamic Utopian: A Political Biography of Alī Sharīatī.( London: I.B. Tauris, 1998).

${ }^{\mathrm{xi}}$ Sharīatī, On the Sociology of Islam, 25.

xii Ibid.,6.

xiii Organization of Intelligence and National Security was the secret police, domestic security and intelligence service established by Iran's Mohammad Reza Shah with the help of the United States' Central Intelligence Agency (the CIA).SAVAK operated from 1957 to 1979 , when the Pahlavi dynasty was overthrown. SAVAK has been described as Iran's "most hated and feared institution" prior to the revolution of 1979 because of its practice of torturing and executing opponents of the Pahlavi regime.

${ }^{\text {xiv }}$ Ali Sharīatī , What Is To Be Done: The Enlightened Thinkers And An Islamic Renaissance, (Houston, 1986).

xv Shamsaei Maryam, Shah Hazim. "Islam, Science and Government according to Iranian Thinkers", International Journal of Humanities and Social Science, Vol. 2 Issue 1 (2013): 67.

xvi Ibid.

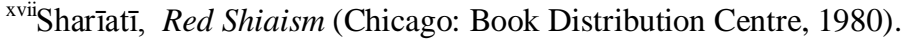

${ }^{\text {xiii }}$ Alī Sharīatī, From where Shall We Begin and The Machine in the Captivity of Mechanism (Ohio: Free Islamic Literature, 1980), 12.

${ }^{\mathrm{xix}}$ Ali Sharīatī, Reflections of Humanity: Two view of Civilization and Plight of Man (Chicago: Book Distribution Centre, 1984),1.

${ }^{\mathrm{xx}}$ Ali Sharīatī, Man and Islam, Translated by Marjani (Houston: FILINC, 1981), 1020.

${ }^{x x i}$ Ali Sharīatī, Martyrdom: Arise And Bear Witness, Tr. by Ghassemy (Teheran, 1981)

${ }^{x x i i}$ Ali Sharīatī, Martyrdom: Arise And Bear Witness. 
xxiii Rehnema, An Islamic Utopian, 9-10.

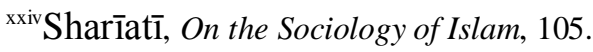

${ }^{\mathrm{xxv}}$ Ibid., 107.

${ }^{x x v i}$ Abrahamian, Ervand. "Ali Shari'ati: Ideologue of the Iranian Revolution", Middle East Research and Information Project, no 102, (1982): 24-28.

${ }^{x x v i i}$ Ali Sharīatī, Religion vs. Religion, trans. Laleh Bakhtiar (Chicago: Kazi Publications, 2010)

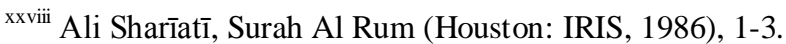

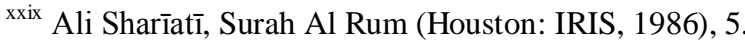

